\title{
Evaluation and comparison of executive functions and false memory in the elderly
}

\author{
Bahram Peymannia $^{1}$, Leila Bitarafan ${ }^{2}$, Amin Hosseini $^{3}$ \\ 1-Assistant Professor of psychology, Shahid Chamran university of Ahvaz, Ahvaz, Iran (Corresponding Author). \\ E-mail: b.peymannia@scu.ac.ir \\ 2- Phd student in psychology, University of Gilan, Gilan, Iran. \\ 3- MA in Clinical psychology, University of Kharazmi, Tehran, Iran.
}

Received: 31/07/2019

Accepted: 26/10/2019

\begin{abstract}
Introduction: Cognitive impairment is a common feature in the elderly and seems to affect other abilities and behaviors of this group.

Aim: The present study aimed at comparing the executive functions and false memory in two age groups of 60-70 years and 71-80 years in Tehran.

Method: This is a causal-comparative descriptive study. The statistical population consisted of all the people above 60 years old attending the Retirement Organization of Tehran in 2018. Two groups of 100 participants were selected for the 60-70-year and 71-80-year groups through the convenience sampling method. The Wisconsin Card Sorting Test (WCST) and the false memory test were used for data collection. The obtained data was analyzed using descriptive statistics and MANOVA.

Results: The results showed that the elderly in the 71-80-year group had poorer performance in WCST than the 60-70-year group. In addition, the false recall and false recognition subscales of false memory were significantly lower in the 60-70-year group than the 71-80-year group.

Conclusion: According to the findings of the present study, executive functions and false memory decrease in the elderly with aging. Therefore, it is very important to provide cognitive empowerment services to enhance the executive functions of the elderly.
\end{abstract}

Keywords: Executive functions, Memory, Elderly

How to cite this article : Peymannia B, Bitarafan L, Hosseini A. Evaluation and comparison of executive functions and false memory in the elderly. Shenakht Journal of Psychology and Psychiatry. 2019; 6 (5): 108-117 .URL: http://shenakht.muk.ac.ir/article-1-606-fa.pdf

Copyright (C) 2018 the Author (s). Published by Kurdistan University of Medical Sciences. This is an open access article distributed under the terms of the Creative Commons Attribution-Non Commercial License 4.0 (CCBY-NC), where it is permissible to download, share, remix, transform, and buildup the work provided it is properly cited. The work cannot be used commercially without permission from the journal. 


\section{بررسى و مقايسه كار كردهاى اجر ائى و حافظه ى كاذب در سالمندان}

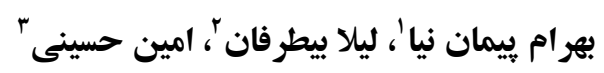

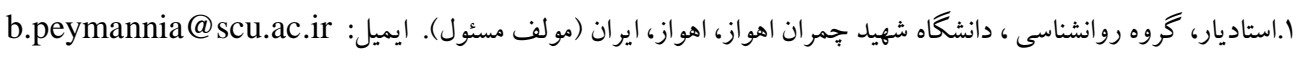
r. دانشجوى دكتراى تخصصى روانشناسى، دانشگاه گيلان، گيلان، ايران. r. كارشناسى ارشد روانشناسى عمومى، دانشگاه خوارزمى، تهر ان، ايران.

مقدمه: نقايص فر آيندهاى شناختى، ويزگ گى معمول افرادسالمند است و به نظر مى رسد هر نقصى در اين فر آيندها مى تواند بر ساير توانايى ها و رفتارهاى ديخر اين خروه تأثير بحذارد.

هدف: هدف يُزوهش حاضر مقايسه كار كردهاى اجرائى و حافظه ك كاذب در دو گروه از سالمندان ·9 تا ·V ساله و اVا •N ساله شهر تهران بود.

روش: تروهش حاضر توصيفى از نوع على-مقايسه اى است. جامعلى آمارى شامل كليه افراد بالاى •q سال مراجعه كننده به سازمان

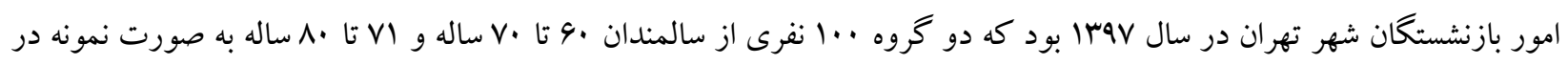
دسترس انتخاب شدند. براى سنجش از آزمون دسته بندى كارت هاى ويسكانسين و آزمون حافظهى كاذب استفاده گرديد. دادهها با باد استفاده از روش آمار توصيفى و مانوا تجزيه و تحليل شد.

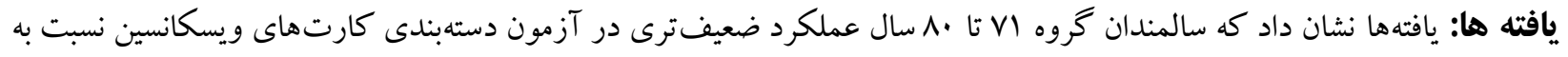

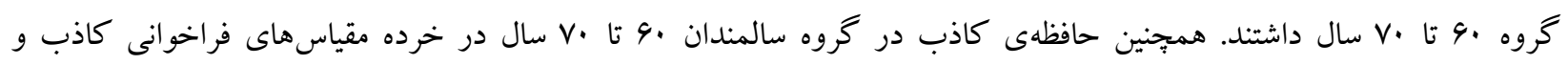

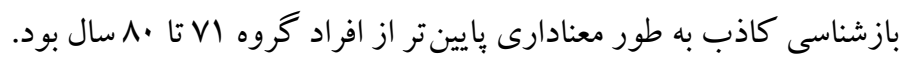
نتيجه كيرى: بر اساس يافتهاى يثزوهش كار كردهاى اجرائى و حافظهى كاذب با افزايش سن در سالمندان رو به ضعف مى گذارند. بنابراين ارائهى خدمات تو انمندى شناختى جهت ارتقاى كار كردهاى اجر ايى سالمندان اهميت ويزهاى دارد. كليد وازه ها: كار كردهاى اجرائى، حافظه، سالمندى 
حجم قطعه بيشانى با افزايش سن در هر سال، هذ/ • درصد مقدمه كاهش مى يابد كه اين ميزان دو برابر ساير نواحى مغزى

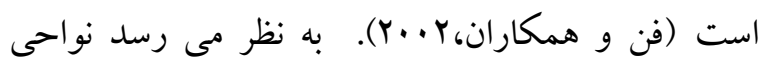
ييشانى و ويش بيشانى مغزى در عملكردهاى شناختى هدف محور كه به عنوان كاركردهاى اجرايى شناخته مى شوند، نقش به سزايى دارند (بازلوسكا و همكاران، . ( .19

يُخوهش ها نشان مى دهد اختلال در شروع و مهار بِاسخ هاى نامناسب همجنان از عوارض شناختى شايع در دوران

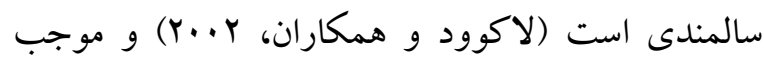
افت كارائى و ناتوانى سالمندان در انجام فعاليت هاى روزانهى آنان مى شود (رويال و همكاران، F....... يثزوهش دويت و شاكتر (19) نشان مى دهد سالمندان حساسيت بيشترى به طيف گسترده اى از خطاهاى حافظه از جمله خطاهاى مبتنى بر آشنايى، خطاهاى مبتنى بر بر بر بـ اعتقادات، خطاهاى اتصال و حافظه كاذب براى اطلاعات مربوط به خود و اطلاعات غلط نشان مى دهند. وجود حافظه ك كاذب نيز در سالمندى امرى متداول است و اين مسئله به معنى داشتن يكك خاطره ى واضح از اشخاص، مكانها، رويدادها و موقعيتهايى است كه هر زز اتفاق

$$
\text { نيفتاده است (دوويت و اسكاكتر، 19 19). }
$$

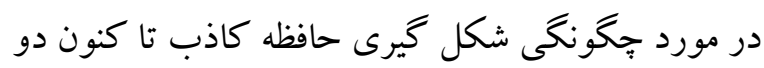
نظريه مطرح شده اند نظريه رديابى مبهم و نظريه همخوانى-فعال سازى. براساس نظريه رديابى مبهم، حافظه هم مى تواند به صورت ردهاى دقيق و هم ردهاى موضوعى (كلى) ذخيره شود و هر دو نوع رديابى با سن تحول ميابند. بر اين اساس حافظه صحيح در ارتباط با ردهاى دقيق است و حافظهى كاذب در ارتباط با ردهاى

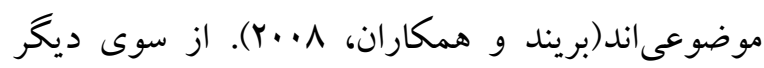
سالمندى فرآيندى است كه با دگر گونىهاى عميق در سه بعد فيزيولوزيكك، روانشناختى و جامعه شناختى انسان همراه است (قربانعلى يور و اسلامى، اهمبا). در سالمندى طبيعى، هر دو نوع فرآيندهاى شناختى كلى و بردازشى خاص تحليل مىيابند. سالمندان دجار كاهش زمان زمان عكس العمل، سرعت حر كات، حافظه كارى، قدرت حل مساله و فعاليتهاى بردازشى جند گانه مىشوند. اخر جّه تغييرات وابسته به سن در توانايىهاى شناختى از اوايل قرن حاضر مستدل شده است. با اين وجود اختلاف نظرهايى در اين زمينه وجود دارد كه آيا كاهش توانايىهاى شناختى بهطور عمومى در همه زمينهاى شناختى روى مىدهد يا اينكه محدود به دامنه خاصى از فعاليت

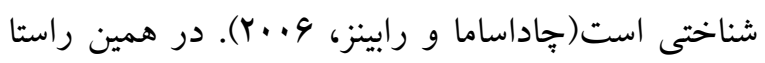
يكى از مهمترين توانمندى هايى كه در دوران سالمندى در كار آمدى زندگى سالمندان نقش برجسته ایى دارد، كار كردهاى اجرايى ناميده مى شود. درواقع كاركردهاى اجرايى مجموعه ایى از مهارتهاست كه به عنوان يكك سازه شناختى مطرح مى شود و وظايفى همدٍون حل مسئله،

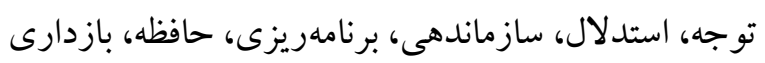

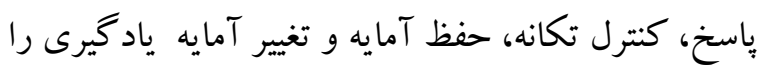
بر عهله دارد. در نتيجه نقص و ناتوانى در اين زمينه ها منجر به اختلال در عملكردهاى روزانه مى شود. به باور ملترز (Y.V.V) هستهى اساسى كاركردهاى اجرايى شامل

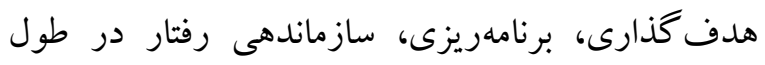
زمان، انعطاف يذيرى، توجه، حافظه فعال و فر آيندهاى خودنظم دهى مىباشد. يُزوهش ها نشان مى دهد عملكرد

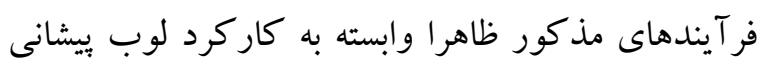

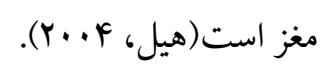


از سالمندان ·9 الى ·V و ال الى •N ساله توسط آزمون هاى ويسكانسين و وبرسشنامه حافظه ى كاذب مورد بررسى قرار كرفت. محققين به افراد شركت كننده در بزوهش اطمينان دادند كه اطلاعات آنها به صورت محرمانه است و نتايج حاصل از يزوهش به صورت كروهى و بدون نام مورد تجزيه و تحليل قرار خواهد

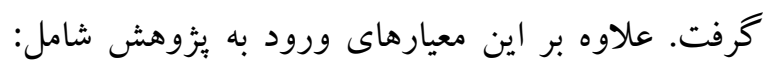

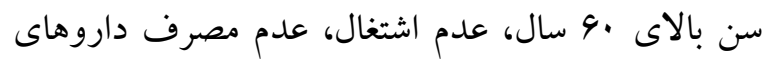
اعصاب و روان و عدم وجود بيمارى جسمانى خاص در شركت كنند كان بود. از سوى ديخر معيار خروج از يثزوهش شامل عدم رضايت آكاهانه جهت شركت در يُّوهش و عدم تكميل برسشنامه ها بود.

ابز ار آزمون دسته بندى كارت هاى ويسكانسين('WCST):

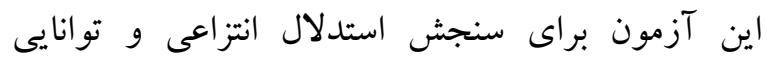
ساز گار كردن راهبردهاى شناختى فرد با جالش هاى إى محيطى طراحى شد. بدين علت، عقيده بر اين است كه آزمون دسته بندى كارت هاى ويسكانسين گستره ييججيدهاى از كنش هاى اجرايى را مى سنجد كه شامل برنامه ريزى، سازماندهى، استدلال انتزاعى، شكل گيرى إنى مفهوم، حفظ قوانين شناختى، توانايى تغيير و بازدارى

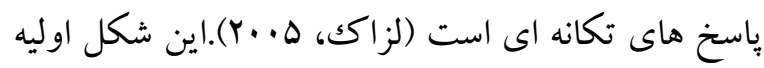
در طول زمان دجار تغيير شد و نسخه بسيار رايج امروزى كه شامل دو دسته كارت محرك است بوجود آمد (هيتون و همكاران، سو199). آزمون دسته بندى كارت هاى ويسكانسين داراى fq كارت است. بر روى كارت ها جهار نوع شكل(مثلث، ستاره، صليب، دايره) جاٍ شده است و تعداد هر يكك از شكل ها بر روى هر كارت
نظريهى همخوانى -فعالسازى، حافظ ى كاذب را محصول فرآيندهاى تداعى كننده و فعالسازى مى داند ( هو و

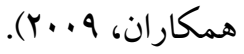
طبق اين ديد كاه بردازش يكك وازه، گره متناظر يا به

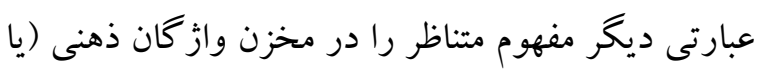
به طور كلى يايگاه دانش) افراد فعال مى كند و اين فعالسازى در امتداد ارائه مى محرك هاى مشابه فعال مى

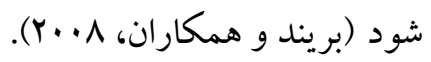
يثزوهش ها نشان مىدهد افزايش حافظهى كاذب در سالمندان ناشى از تغييرات در لوب ميانى بيشانى و قشر

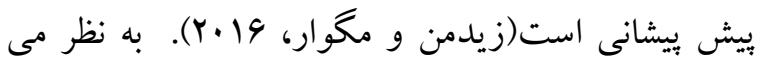
رسد همان نواحى كه در كاركردهاى اجرايى داراى نقش و اهميت برجسته اى هستند در شكل گيرى حافظهى كاذب سالمندان نيز نقش اساسى ايفا مى كنند. از اين رو با توجه به فقدان يزوهشى از اين دست در كشور كه به بررسى نقش كاركردهاى اجرايى و حافظه كى كاذب در سالمندان ببردازد، اين برسش مطرح مى شود كه آيا ميان كاركردهاى اجرايى و حافظه كاذب دو گروه از سالمندان تفاوت وجود دارد؟ يزؤهش حاضر يك مطالعه ى توصيفى از نوع على - مقوس مقايسه اى است. بر اين اساس جامعه ى مورد مطالعهى

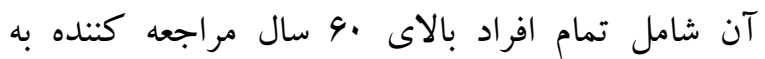
سازمان امور بازنشستگان شهر تهران در سال Vqrا بود.

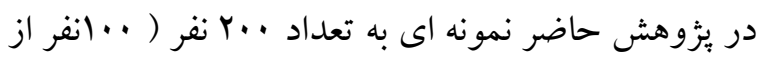

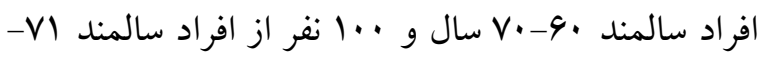

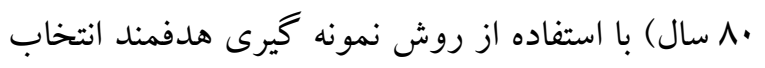
شد. سبس كاركردهاى اجرايى و حافظه كاذب دو گروه

\footnotetext{
${ }^{1}$. Wisconsin Card Sorting Test
} 
فهرست ارايه مى شود. يّ از ارايه همه فهرست ها، آزمون بازشناسى اجرا مى شود.در اين آزمون (كه شامل كلمه هاى ارايه نشده، كلمه هاى كليدى ارايه نشده و كلمه هاى اضافى است)، شركت كننده بايد مشخص كند كه كدام كلمه جز فهرست هاى ارايه شده است و كدام كلمه جز آنها نيست. اين برنامه يكك روش آسان و معتبر براى مطالعه يادآورى و بازشناسى حافظه كاذب در فرايندهاى تداعى كننده فراهم كرده است. بر اساس بر بر

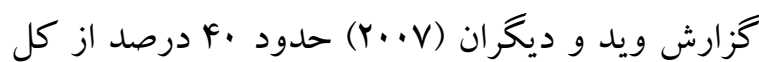
بزوهش هايى كه تا سال F...... در زمينه حافظه كاذب انجام گرفته اند از مقياس مذكور استفاده كرده اند. اين موضوع خود مويد اعتبار اين ابزار است و آن را به عنوان ابزارى قدرتمند معرفى مى كند. علاوه بر اين استدلر، روديخر و مكك درمت (1999) با استفاده از روش دونيمه كردن، اعتبار آزمون ياداورى و بازشناسى را محاسبه كرده اند. اين إزوهشخران، ضريب همبستخى دو نيمه كردن را براى آزمون ياداورى ·^/، • و براى آزمون

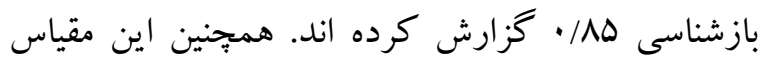
توسط نجاتى، كمرى، رادفر و شيرى (Y Y.r) در جامعه ايرانى هنجار شده و فرم ايرانى اين آزمون از روايى و يا يايیى مطلوبى برخوردار است.

يافته ها اين مطالعه در دويست سالمند در دامنه سى سنى .9 تا • سال صورت گرفت. به منظور بررسى متغيرهاى يزوهش از روش آمار توصيفى و استباطى استفاده شد. در مرحله

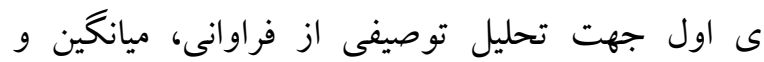
انحراف معيار استفاده شد. سبس ميانخين دو گروه بوسيله ى آزمون تحليل واريانس جند متغيرى (مانووا) مورد

$$
\text { مقايسه قرار گرفت. }
$$

از يكك تا جهار در نوسان مى باشد. در ضمن هر يك از كارتها به يكى از رنگك هاى جهار كانه (آبى، قرمز،سبز، زرد) رنگگ آميزى شده است. به اين ترتيب آزمون داراى سه اصل شكل(جهار نوع)، تعداد جهار حالت و جهار

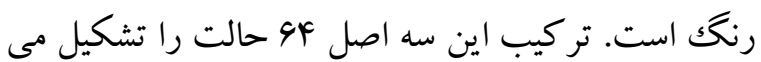
دهد. در واقع هر يكك از كارتها نمايانگر يكك حالت مى باشد كه مشابه هيج يك از كارت هاى ديكر نيست.

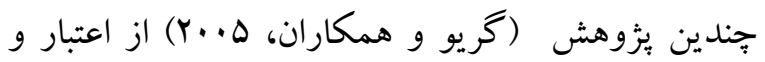
بايائى آزمون دسته بندى كارت هاى ويسكانسين حمايت كرده اند. اكسلرود و همكاران، اظهار مى دارند كه روائى ميان ارزياب ها، در حد عالى و بالاى rA/•است و نيز اعتبار آزمون را با استفاده از روش آزمون _ـباز آزمون،

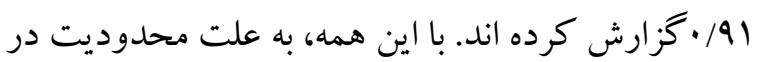
هنجاريابى اين آزمون در ايران، جهت استفاده از آن بايد جوانب احتياط را در نظر كرفت. آزمون حافظه ى كاذب: در بزوهش حاضر براى بررسى حافظه كاذب از مقياس ديس-روديخر-مكك درمت بهره گرفته شد. ديس اين مقياس را براى ('DRM) اولين بار در سال 1909 به كار برده است و روديگر و مكك درمت آن را بار ديگر در سال 1990 ارتقا داد. در اين مقياس به شركت كنندكان فهرست هايى حاوى كلمه هايى ارايه مى شود كه هر يكك از آنها به طور معنايى به يكك كلمه ارايه نشده، يعنى كلمه كليدى ارتباط دارند (براى مثال شركت كنند گان كلمه هايى مانند رخنخواب، استراحت، بيدار، خسته و غيره كه با كلمه ارايه نشده "خواب" ارتباط دارند، مى شنوند). بِ از ارايه هر فهرست آزمون يادآورى آزاد اجرا مى شود و سبس فهرست بعدى و آزمون ياداورى مربوط به آن

\footnotetext{
${ }^{1}$. Deese-Roediger-McDermott
} 
هم در مردان از كمترين فراوانى برخوردار بوده و بيشترين فراوانى مربوط به مدرك دييلم در هر دو جنسيت است. علاوه بر اين مدارك بالاتر از دييلم در مردان با فراوانى

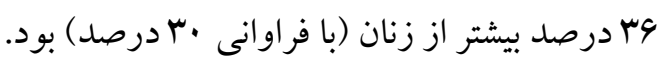
جدول شماره ى | شاخص هاى توصيفى مربوط به

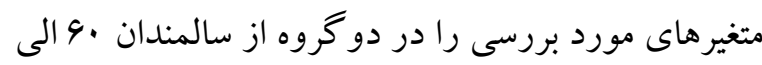

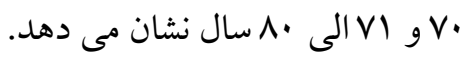

تحصيلات زنان زير دييلم ها نفر، دييلم

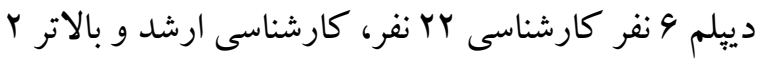
نفر و يكك نفر هم تحصيلات نامشخص داشت. تحصيلات

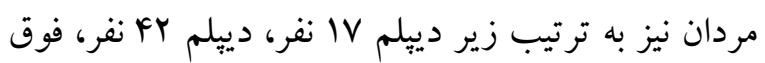
دييلم · انفر كارشناسى 11 نفر، كارشناسى ارشد و بالاتر ^ ن نفر و ه نفر هم تحصيلات نامشخص داشتند. در مجموع مدارك كارشناسى ارشد و بالاتر هم در زنان و

جدول ا ميانكين و انحر اف معيار متغيرهاى يخوهش در دو كروه سالمندان

\begin{tabular}{|c|c|c|c|c|}
\hline \multicolumn{2}{|c|}{ افراد سالمند الY-^ سال } & \multicolumn{2}{|c|}{ 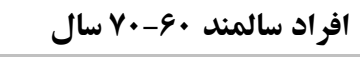 } & \multirow[t]{2}{*}{ متغير هاى پئوهش } \\
\hline انحر اف استاندارد & ميانگين & انحر اف استاندارد & ميانگين & \\
\hline $1 / 90$ & $F / \mu \Delta$ & $1 / 4 \mu$ & $\Delta / Y \wedge$ & تعداد طبقات \\
\hline $9 / 1 V$ & $Y F / \Delta F$ & F/GF & $r \cdot / r \cdot$ & خطاى درجاماندكى \\
\hline $9 / 91$ & $r G / Y I$ & $\Delta / ৭ ৭$ & $r \cdot / \wedge \Delta$ & خطاى خاص \\
\hline T//1 & $\Delta / Y F$ & $1 / \mathrm{r} \Lambda$ & $F / V q$ & فراخوانى كاذب \\
\hline $1 / 1 V$ & $F / F 1$ & $1 / Y 9$ & $F / \cdot q$ & بازشناسى كاذب \\
\hline
\end{tabular}

اساس آزمون لوين هيج يك از متغيرهاى مورد بثوهش قبل از استفاده از آزمون هاى بارامتريك تحليل واريانس

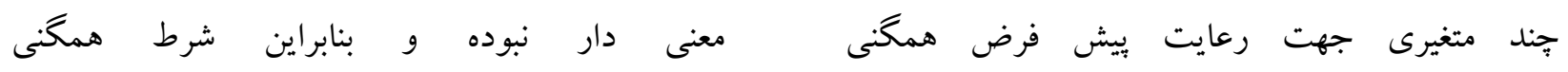

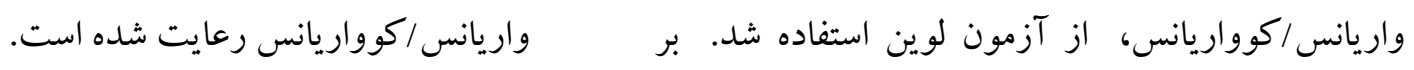

جدول r آزمون معنادارى تحليل واريانس در متغيرهاى مورد يخوهش

\begin{tabular}{|c|c|c|c|c|c|}
\hline معنادارى سطح & خطاى درجه & فرضيه درجه & فراوانى & 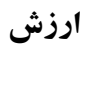 & \\
\hline.$/ .1$ & 199 & r & IV/AYA & $\cdot /$ VA9 & لامبداى ويلكز آزمون ويسكانسين \\
\hline.$/ .4 q$ & 199 & r & $r / r q$. &.$/ 991$ & لامبداى ويلكز حافظه كاذب \\
\hline
\end{tabular}

سال از لحاظ نمرات آزمون ويسكانسين و آزمون حافظه كاذب تفاوت معنى دار وجود دارد. در جدول r نتايج حاصل از آزمون اثرات بين آزمودنىها آمده است.
همانطور كه نتايج جدول r نشان مى دهد ، سطوح معنادارى همه آزمون ها بيانگر آن هستند كه بين دول هور

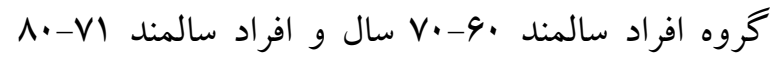


جدول r نتايج تحليل واريانس تفاوت كروه ها در متغيرهاى بروهش

\begin{tabular}{|c|c|c|c|c|c|c|}
\hline اثدازه & معنادارى سطح & فراوانى & مجذانكين & آزادى & مجذورات & متغير وابسته \\
\hline$\cdot / \cdot \Delta F$ &.$/ .1$ & M/YYQ & $F T / \Delta V \Delta$ & 1 & Kr/DVD & تعداد طبقات \\
\hline . INT & $\% \cdot \cdot 1$ & $r \cdot / r \mid r$ & NQN/194 & 1 & 19N/194 & خطاى درجاماندكى \\
\hline.$/ 1 F A$ &.$/ \cdot 1$ & $M F / M \Delta$ & Ifre/9WV & 1 & $1 F r 9 / 9 W$ & خطاى خاص \\
\hline.$/ \cdot \Delta V$ & $\cdot / \cdot r$ & $\Delta / F V r$ & $1 . / 1 F$. & 1 & $1 . / 14$. & فراخوانى كاذب \\
\hline.$/ \% v$ & $\%$ & D/Mrr & १/৭९० & 1 & १/१९० & بازشناسى كاذب \\
\hline
\end{tabular}

بر اين اساس در ئزوهش حاضر كاركردهاى اجرايى دو

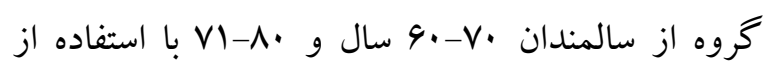
آزمون ويسكانسين مورد بررسى قرار گرفت. با توجه به

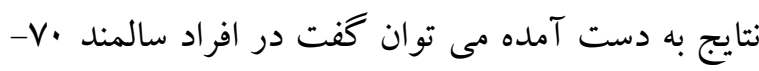
4 سال تعداد طبقات به طور معنادارى بالاتر از افراد. سالمند • •l-1 سال است. اين در حالى است كه خطاى درجاماندگى و خطاى خاص به طور معنادارى در افراد

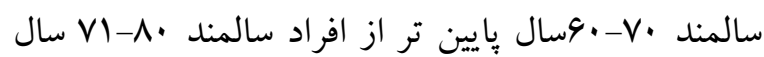
مى باشد. در همين راستا مطالعات بيشين نشان مى دهد كه در سنين سالمندى نقايص انتخابى در كاركردهاى اجرائى مغز فراتر از نقايص كلى در فر آيندهاى شناختى

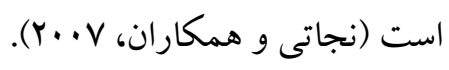

در مجموع اين يافته با ئزوهش هاى فيتز ياتريك (Y)

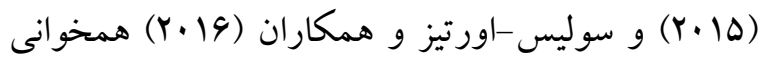
دارد. در تبيين اين نتايج مىتوان كفت سالمندانى كه در تكليف درجاماندگى و خطاى خاص مشكل دارند نمىتواند اطلاعاتى را كه به آنها نيازى ندارند، ناديده بكيرند و يكك فكر يا عمل را به صورت ناگهانى متوقف سازند. همجينين كنترل ناقص بازدارى اجرايى مىتواند توانايى حافظه
همانطور كه در جدول ب ملاحظه مى شود، بين دو گروه افراد سالمند •9-•V سال و افراد سالمند الV-•^ سال در

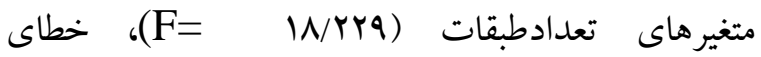

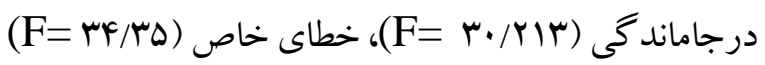

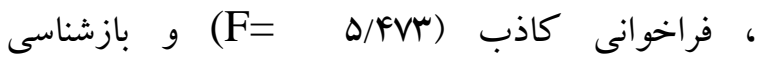
تفاوت معنادار وجود دارد. كه با توجه به (F= (F/r تفاوت ميانگين دو گروه در آزمون هاى مذكور مندرج در جدول شماره ى ا جنين استنباط مى شود كه افراد

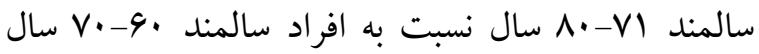
عملكرد ضعيف ترى در كاركردهاى اجراى داشته اند.

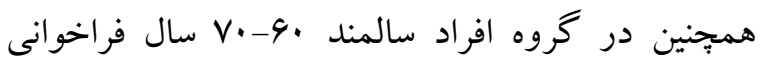
كاذب و بازشناسى كاذب به طور معنادارى پايين تر از

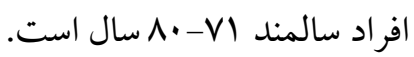
امروزه توافق بايه اي بر روى اين مطلب وجود دارد كه

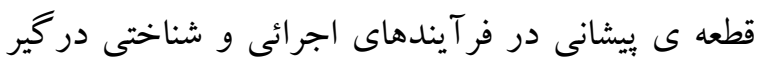
است. بر اين اساس تغييرات وابسته به سن، بيشتر در

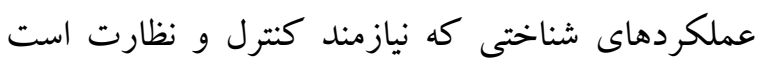

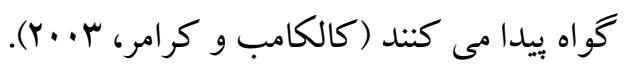


توجه به افت كار كردهاى اجرايى تحليل مى رود (بريند و

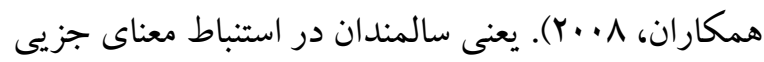
فهرست هاى تداعى كننده و حافظه ى كارى به عنوان يكى از اجزا كاركردهاى اجرايى با ناتوانايى هايى مواجه هستند و همين امر در شكل گيرى حافظه كاذب سالمندان دخيل است. از سوى ديخر بر اساس نظريه هو و همكاران

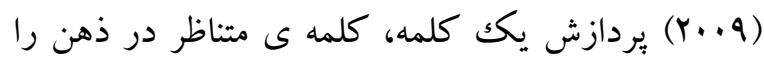
فعال مى كند و اين فعال سازى در طى ارائه كى كلمه هاى فهرست مورد يزوهش ادامه مى يابد. بنابراين جنانجه ذخيره دانش بيشين فرد با توجه به تحول و رشد سن بسط يافته تر و تجربيات او وسيع تر باشند و از سوى ديخر بازدارى يُاسخ هاى نامرتبط در وى با توجه به افت كار كردهاى اجرايى محقق گردد، به نظر مى رسد احتمال فعال سازى كلمه كليدى مشابه در خزانه ى ذهنى سالمندان و در نتيجه افزايش حافظه ك كاذب را به دنبال خواهد داشت. بدين ترتيب قابل توجيه است سالمندان

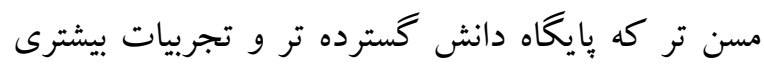
دارند، با توجه به افت كاركردهاى اجرايى حافظه كاذب

$$
\text { بيشترى داشته باشند. }
$$

از سوى ديخر در راستاى ارتقاى توانمدى شناختى سالمندان نتايج بثوهش بورلا و همكاران (Y.lV) نشان مى دهد سالمندانى كه عملكرد شناختى ضعيف ترى در مقايسه با ديخر سالمندان دارند، بيشتر از رويكردهاى مبتنى بر ارتقاى توانمندى شناختى بهره مى برند(بورلا و

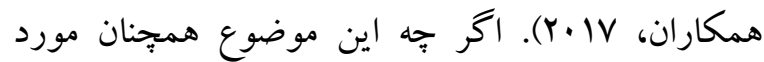
بحث ميان صاحب نظران است با اين وجود برخى از يثزوهشكران معتقدند سالمندان با عملكرد شناختى بايين تر بتانسيل يادگيرى بيشترى در مقايسه با ديخر سالمندان

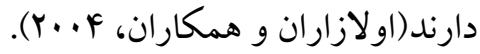

كارى را به خطر بياندازد و به تخريب حافظه ى كارى منجر شود (والرا و سيدمن، 4. (Y). با توجه به اينكه انتخاب محر كک، انتخاب پِاسخ و تكليف اجراى باسخ هر فرد نيازمند بازدارى در مراحل متفاوت بردازش اطلاعات است (كستى و همكاران، I. (Y). بنابر اين به نظر مى رسد سالمندانى كه مشكلات بيشترى در بازدارى بِاسخ دارند، در تكاليف مربوط به آزمون ويسكانسين با خطاى بيشترى مواجه ميشوند. علاوه بر اين بثزوهش ها به اهميت

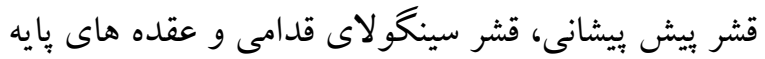
با توجه به افزايش سن در كنترل شناختى نيز اشاره دارد،

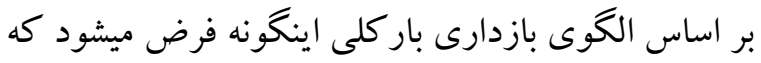
عملكرد درست كاركردهاى اجرايى به عملكرد درست بازدارى در كورتكس بيشانى و بيش بيشانى بستگى دارد. به بيان ديخر وقتى بازدارى مشكل دارد، ديخر

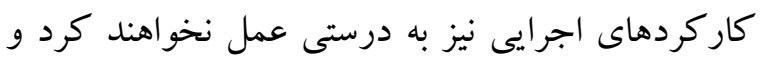

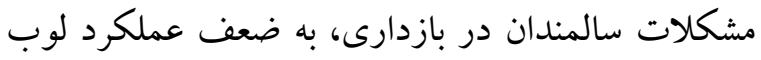
ييشانى و بيش بيشانى آنها مربوط مى شود. علاوه بر اين ديخر يافته هاى بزّوهش نشان داد افراد سالمند گرووه •V-V.9 سال در مقايسه با افراد سالمند گروه . V سال از فراخوانى كاذب و بازشناسى كاذب (حافظه كاذب) كمترى برخوردار هستند. كه اين نتايج با

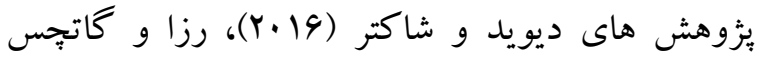
و (Y.|r)

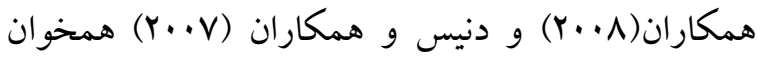
در تبيين نتايج مذكور مى توان كفت افت كاركردهاى اجرايى همسو با افزايش حافظه ى كاذب در سالمندان است. به عبارتى بر اساس نظريه رديابى مبهم برينرد و

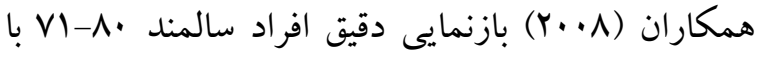


review of data and theory. Psychological bulletin, 134(3):343.

Brainerd CJ, Yang Y, Reyna VF, Howe ML, Mills BA. (2008). Semantic processing in "associative" false memory. Psychonomic Bulletin \& Review, 15(6):1035-53.

Buczylowska D, Daseking M, Petermann F. (2016). Age-related differences in the predictive ability of executive functions for intelligence. Zeitschrift für Neuropsychologie, Sep 20.

Buczylowska D, Petermann F. (2016). Age-related differences and heterogeneity in executive functions: analysis of $\mathrm{NAB}$ executive functions module scores. Archives of Clinical Neuropsychology,31(3):254-62.

Casty BJ, Durston S, \& Fossella JA. (2001). Evidences for a mechanistic model of Cognitive control. Journal of Clin Neuroscience Research, 4(3), 267-282.

Chudasama Y, Robbins TW. (2006). Functions of frontostriatal systems in cognition: Comparative neuro psychopharmacological studies in rats, monkeys and humans. Biol Psychol, 73:19-38.

Colcombe S, Kramer AF. (2003). Fitness effects on the cognitive function of older adults: a metaanalytic study. Psychological science, 14(2):125-30.

Dennis NA, Kim H, Cabeza R. (2007). Effects of aging on true and false memory formation: an fMRI study. Neuropsychologia, 45(14):3157-66.

Devitt AL, Schacter DL.(2016). False memories with age: Neural and cognitive underpinnings. Neuropsychologia, 1;91:346-59.

Fan J, McCandliss BD, Sommer T, Raz A, Posner MI (2002). Testing the efficiency and independence of attention networks. J Cogn Neurosci, 14:340-7.

Fitzpatrick S, Gilbert S, \& Serpell L. (2013). Systematic review: are overweight and obese individuals impaired on behavioral tasks of executive functioning? Neuropsychology Review, 23(2), 138-156.

Ghorbanalipour M, Ismail A. (2012) determining a significant effect on the anxiety of death in the

$$
\begin{aligned}
& \text { نتيجه تيرى } \\
& \text { در بايان مىتوان كَت همانگًونه كه نتايج بثروهش نشان } \\
& \text { مى دهد كار كردهاى اجرائى و حافظه ك كاذب سالمندان } \\
& \text { با افزايش سن رو به ضعف مى گذارند. بنابراين در تدوين } \\
& \text { برنامهاى كاربردى از سوى وزارت بهداشت، درمان و } \\
& \text { آموزش يزشكى بايد برنامه هاى مبتنى بر ارتقاى } \\
& \text { توانمندى هاى شناختى براى سالمندان در كانون توجه } \\
& \text { قرار گيرد. از آنجايى كه نمونه گيرى به صورت در } \\
& \text { دسترس بود، براى قابليت تعميمدهى نتايج بايد جانب } \\
& \text { احتياط صورت يذيرد. علاوه براين بيشنهاد مىشود در } \\
& \text { يثزوهش هاى آتى نقش ساير متغيرهاى تعديل گر از جمله } \\
& \text { : محل زند گىى (آسايشگاه يا خانواده)، جنسيت، طبقه ى } \\
& \text { اقتصادى، اجتماعى و هوشى سالمندان نيز مورد مطالعه }
\end{aligned}
$$

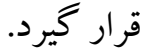

$$
\begin{aligned}
& \text { سياسگز ارى } \\
& \text { در انتها بدين وسيله از تمامى سالمندان و مسئولان سازمان } \\
& \text { بازنشستخان كشورى كه در اين بثوهش ما را يارى نموده } \\
& \text { اند، كمال تشكر و قدردانى را مىنماييم. }
\end{aligned}
$$

\section{References}

Aslan AK, Starr JM, Pattie A, \& Deary I. (2015). Cognitive consequences of overweight and obesity in the ninth decade of life? Age Ageing, 44(1), 59-65.

BorellaE, Carbone E, Pastore M, De Beni R, Carretti B. (2017). Working memory training for healthy older adults: the role of individual characteristics in explaining short-and longterm gains. Frontiers in human neuroscience, 11:99.

Brainerd CJ, Reyna VF, Ceci SJ. (2008). Developmental reversals in false memory: A 
elderly (Persian). Joumal of Consulting Culture, 3(9):53-68.

Greve KW, Stickle TR, Love JM, Bianchini KJ, Stanford MS. (2005). Latent structure of the Wisconsin Card Sorting Test: a confirmatory factor analytic study. Archives of Clinical Neuropsychology, 20(3):355-64.

Heaton RK, Chelune GJ, Talley JL, Kay GG, Curtiss G. (1993). Wisconsin Card Sorting Test (WCST): Manual: Revised and Expanded. Psychological Assessment Resources (PAR).

Hill EL. (2004) Executive dysfunction in autism. Trends in Cognitive Sciences, 122, 274-289.

Howe ML, Wimmer MC, Gagnon N, Plumpton S. (2009). An associative-activation theory of children's and adults' memory illusions. Journal of Memory and Language, 1;60(2):229-51.

Lee YS, Lee CL, Yang HT. (2012). Effects of aging and education on false memory. The International Joumal of Aging and Human Development, 74(4):287-98.

Lezak M. (2005). Neuropsychological assessment. 3rd ed. New York: Oxford University Press.

Lockwood CA, Alexopoulos GS, Gorp WG. (2002). Executive dysfunction in geriatric depression. Am J Psychiatry, 159:1119-26.

Miller AL, Jong H, \& Lumeng, JC. (2015). ObesityAssociated Biomarkers and Executive Function in Children. Pediatric Research, 77(1), 143-147.

Naderi F, Roushani KH. (2011). Relation between spiritual intelligence, social intelligence and death anxiety in Ahwaz woman senile. Woman Cult, 2(6): 55-67.

Nejati V, Ashayeri H, Garosi-Farshi MT, Aghdasi MT.(2007). Effect of dual task interference in implicit and explicit learning of motor sequence in the elderly and young (persian). $\mathrm{J}$ Cogn Sci, 9(1):16-21.

Olazaran J, Muñiz R, Reisberg B, Peña-Casanova J, Del Ser T, Cruz-Jentoft AJ, Serrano P, Navarro E, de la Rocha MG, Frank A, Galiano M. (2004). Benefits of cognitivemotor intervention in $\mathrm{MCI}$ and mild to moderate Alzheimer disease. Neurology, 63(12):2348-53.

Piguet O, Connally E, Krendl AC, Huot JR, Corkin S. (2008). False memory in aging: Effects of emotional valence on word recognition accuracy. Psychology and aging, 23(2):307.

Rosa NM, Gutchess AH. (2013). False memory in aging resulting from self-referential processing. Joumals of Gerontology Series B: Psychological Sciences and Social Sciences, 68(6):882-92.

Royall DR, Palmer R, Chiodo LK, Polk MJ. (2004). Declining executive control in normal aging predicts change in functional status: The freedom house study. J Am Geriatr Soc, 52:346-52.

Solis-Ortiz S, Gutiérrez-Muñoz M, MoradoCrespo L, Trejo-Bahena SA, \& Kala L. (2016). Executive Functions Correlated with Body Mass Index in Overweight Middle-Aged Women. Psychology, 7, 410-417.

Soury A, Shabani Moghadam K, Soury R. (2016) The effect of physical activity on quality of life in elder women in Kermanshah province. Appl Res Sport Manage ,4(16):75-84. 2

Valera EM, \& Seidman LJ. (2006). Neurobiology of Attention-Deficit/Hyperactivity Disorder in Preschoolers. Joumal of Infants and Young Children, 19(2), 94-108.

Zeidman P, Maguire EA. (2016). Anterior hippocampus: the anatomy of perception, imagination and episodic memory. Nature Reviews Neuroscience, 17(3):173. 